\title{
Beretning om Grundtvig-Selskabets virksomhed 1971-1972
}

Ved styrelsesmødet på Rødding Højskole i september I970 nedsattes et arbejdsudvalg bestående af selskabets formand og næstformand samt professor Gustav Albeck og mag. art. Hellmut Toftdahl. Udvalget optog straks forhandling med Det danske Sprog-og Litteraturselskab om en udgivelse af Grundtvigs breve og dagbøger. Resultatet blev, at Litteraturselskabet besluttede først at iværksætte en fuldstændig udgave af Grundtvigs dagboger efter en af Grundtvig-Selskabet skitseret plan, udarbejdet af Gustav Albeck, som forestår udgivelsen. Arbejdet er godt igang, men planen om at udgivelsen skulle ske til Ioo-års dagen for Grundtvigs død den 2. september 1972 har desværre ikke kunnet gennemføres. Men det vigtigste er, at udgaven kommer, og på Grundtvig-Selskabets vegne takker jeg Det danske Sprog- og Litteraturselskab for genoptagelsen af det gode samarbejde, som tidligere har resulteret i den store udgivelse af Registrant over N. F. S. Grundtvigs papirer.

I løbet af I97 I kom vort selskab i økonomiske vanskeligheder. Udgivelsen først på året af ny brochure om selskabet, dets virksomhed og publikationer, i I.750 eksemplarer, hvoraf I.500 blev tilsendt danske præster - eksemplarer til interesserede kan stadig fåes ved henvendelse til selskabets kontor - betød en ekstra udgift på 2.25 I kr. Hertil kom stigningen i trykningsomkostninger ved udsendelsen i efteråret af Grundtvig-Studier 1971, som var et par ark større end foregående år og kostede $19.872 \mathrm{kr}$. (medens årgang 1970 kostede $14.760 \mathrm{kr}$.). Disse øgede udgifter nødte selskabet til at stifte et mindre lån på $3.500 \mathrm{kr}$., og for at klare den betrængte situation vedtog forretningsudvalget i september $197 \mathrm{I}$ dels at forhøje kontingentet til $25 \mathrm{kr}$. ( $15 \mathrm{kr}$. for studerende), på forventet efterbevilling fra styrelsens og medlemmernes side, dels traf man med stor beklagelse den beslutning at aflyse årsmødet for 197 I for at spare de dermed forbundne udgifter. Meddelelsen om årsmødets aflysning og kontingent-forhøjelsen blev tilstillet medlemmerne samtidig med udgivelsen af GrundtvigStudier I97I, og det blev oplyst at hensigten også var at gøre det økonomisk muligt at afholde et udvidet årsmøde i 1972 i forbindelse med et Internationalt Seminar om »Grundtvig og vor tid« med særligt henblik på at belyse virkningen af Grundtvigs tanker uden for Danmark.

Det var oprindeligt tanken, at dette stævne - med Ioo-året for Grundtvigs dødsdag i minde - skulle holdes fra 30. august til 3. september I972. I december besluttede forretningsudvalget imidlertid at indgå samarbejde med $D e t$ danske Selskab, som under ledelse af direktør Folmer Wisti havde planlagt et lignende seminar $\gg A$ century after Grundtvig« på Den internationale Højskole 
i Helsingør i midten af august. I gensidig erkendelse af det uheldige i næsten samtidig at afholde to internationale møder med til dels samme talere, besluttede de to selskaber i forening at indbyde til internationalt Grundtvig-Seminar den I3.-I9. august 1972. Grundtvig-Selskabet kunne således ved i forbindelse med seminaret at afholde årsmødet, give dette et særlig indholdsrig program, som kan tjene til at markere, at selskabet $i$ år fejrer 25 -året for sin oprettelse.

Takket være dette samarbejde med Det danske Selskab kunne antallet af talere og mødedage udvides, og alle deltagere modtager Det danske Selskabs udgivelse af dr. theol. Kaj Thanings skrift på engelsk om Grundtvig. Som tilskud til seminaret har selskabet med tak modtaget $15.000 \mathrm{kr}$. fra Undervisningsministeriet og $10.000 \mathrm{kr}$. fra Kirkeministeriet. Endvidere har selskabet i 197 I, ligesom i 1970 - og påny i indeværende år - haft den glæde at modtage tilskud til driften på $4.000 \mathrm{kr}$. årligt fra Undervisningsministeriet og på I.000 kr. årligt fra Carlsen-Langes Legatstiftelse.

Henning Høirup 